\author{
Dariusz Karkosiński \\ Pawet Stromski \\ Natalia Karkosińska Brzozowska \\ Politechnika Gdańska
}

\title{
Hybrid energy storage for electric multiple units to operate at the partially electrified line Gdynia - Hel
}

\author{
Hybrydowy zasobnik energii dla elektrycznych zespołów \\ trakcyjnych do obsługi częściowo zelektryfikowanej linii Gdynia - Hel
}

\begin{abstract}
The article presents calculations enabling the selection of an on-board energy storage device to replace diesel-powered trains with modern storage multiple units on the example railway line Gdynia Gtówna - Hel. The pioneering and currently used storage electric multiple units, mainly in Europe, were presented. The condensed results of the inventory of the line in question, including the technical condition of the stations of the non-electrified line $213 \mathrm{Reda}-\mathrm{Hel}$, are included. Moreover, an analysis of the terrain possibilities of building new passing loops aimed at increasing the capacity of line 213 is presented. The calculations of the theoretical passage and energy demand of the storage train unit on the non-electrified part of the analyzed route are presented. The results of the calculations were used to select the on-board energy storage consisting of batteries and supercapacitors.
\end{abstract}

$W$ artykule przeprowadzono obliczenia pozwalajace na dobór pokładowego zasobnika energii do zastapienia pociagów z napędem spalinowych przez nowoczesne zasobnikowe zespoty trakcyjne na przykladowej trasie Gdynia Główna - Hel. Przedstawiono pionierskie oraz obecnie stosowane zasobnikowe elektryczne zespoly trakcyjne, głównie w Europie. Zamieszczono skondensowane wyniki inwentaryzacji rozpatrywanej linii, w tym stan techniczny stacji i przystanków niezelektryfikowanej linii 213 Reda - Hel. Ponadto przedstawiono analizę terenowych możliwości budowy nowych mijanek majacych na celu zwiększenie przepustowości linii 213. Zaprezentowano obliczenia przejazdu teoretycznego oraz zapotrzebowania energetycznego zasobnikowego zespotu trakcyjnego na niezelektryfikowanej części analizowanej trasy. Wyniki przeprowadzonych obliczeń wykorzystano do doboru pokładowego zasobnika energii składajacego się z baterii akumulatorów oraz superkondensatorów.

\section{WSTĘP}

Non-electrified railway lines in Poland are served only by diesel traction vehicles. Their operation has a negative impact on the local natural environment as a result of the emission of toxic exhaust components. In addition, in areas attractive to tourists, passenger diesel multiple units are burdensome due to noise generated by diesel engines and their ventilation systems, especially when starting from a standstill on lines with a large number of stops. With a conservative approach, the only alternative to internal combustion vehicles is the costly electrification of the line and the equally costly subsequent maintenance. Electric units are characterized by greater traffic dynamics, which is important in urban sections. On lines that are mainly used for passenger transport, combustion-powered vehicles can be replaced by electric multiple units with an on-board energy storage. Their introduction to traffic may be much cheaper than the reconstruction of the traction network, which also disturbs the local landscape.

\section{WSTĘP}

Niezelektryfikowane linie kolejowe w Polsce sa obsługiwane wyłącznie przez spalinowe pojazdy trakcyjne. Ich eksploatacja wpływa negatywnie na lokalne środowisko naturalne w wyniku emisji toksycznych składników spalin. Ponadto na obszarach atrakcyjnych turystycznie pasażerskie spalinowe zespoły trakcyjne są uciążliwe $\mathrm{z}$ powodu generowanego hałasu przez silniki Diesla i ich układy wentylacji, szczególnie podczas ruszania z postoju na liniach o dużej liczbie przystanków. Przy konserwatywnym podejściu jedyną alternatywą dla pojazdów spalinowych jest kosztowna elektryfikacja linii i równie kosztowne późniejsze jej utrzymanie. Zespoły elektryczne charakteryzują się większą dynamiką ruchu, co jest istotne na odcinkach o charakterze miejskim. Na liniach służących głównie przewozom pasażerskim można pojazdy $\mathrm{z}$ napędem spalinowym zastapić elektrycznymi zespołami trakcyjnymi z pokładowym zasobnikiem energii. Ich wprowadzenie do ruchu może być znacznie tańsze od odbudowy sieci trakcyjnej, która 
The article considers the technical, economic and ecological aspects of increasing the insufficient rail line capacity and introducing storage electric multiple units for passenger service on a partially electrified line in one of the most attractive tourist regions of the Polish coast. The selected railway line Gdynia Główna - Hel was analyzed, it is characterized by a very high tourist traffic load, running through the Hel Peninsula, which is fully protected by the natural environment under the Natura 2000 Program [20].

\section{IMPLEMENTATION OF RAIL VEHICLES WITH ENERGY STORAGE IN EUROPE}

Such solutions were initiated by the Japanese in 2007 when the innovative NE-Train hybrid multiple unit ("New Energy Train") was put into operation, in which the diesel engine was replaced with electric motors and a battery of batteries [1]. After a series of tests, the traction unit designated EV-E301 was put into operation, which in 2014 began to service the Utsunomiya - Karasuyama line consisting of two sections, electrified with a length of $11.7 \mathrm{~km}$ and nonelectrified with a length of $20.4 \mathrm{~km}$ with 6 stops .

At the same time, in 2014, the Japanese concern Hitachi built a multiple unit series BEC819 with a battery with an energy of $380 \mathrm{kWh}$ and a voltage of 1600 $\mathrm{V}$ [3]. This vehicle was put into service on the 10.8 $\mathrm{km}$ long non-electrified Chikuhō line. In 2018, the BEC819 series unit was also put into service on the non-electrified Kashii line [4]. The EV-E801 series twin construction unit has been used since March 2017 on the $13.3 \mathrm{~km}$ long section of the electrified $\mathrm{Ou}$ line and the $26.6 \mathrm{~km}$ section of the non-electrified Oga line [5]. In 2015, the first European tests of a traction storage vehicle called IPEMU (Independently Powered Electric Multiple Unit) were carried out in Great Britain. The vehicle was built on the basis of the Bombardier Electrostar class 379 electric unit, powered from the $25 \mathrm{kV}, 50 \mathrm{~Hz}$ alternating voltage network, which was equipped with a lithium-ironmagnesium-phosphate battery. This vehicle, tested on a route of $15.1 \mathrm{~km}$ [9], although not finally introduced into linear traffic, initiated an almost avalanche development of such solutions in Europe.

In 2017, Stadler unveiled a new vehicle called WINK, 18 copies of which were ordered by the Dutch carrier Arriva Netherlands. Equipped with electric drive motors, this vehicle can be configured in three ways. The first is to use a conventional diesel engine that runs on either diesel or hydrogenated vegetable oil (HVO). The vehicle can also be equipped with a hybrid drive, consisting of an internal combustion engine driving a generator and a traction power system. The last, most environmentally friendly drive configuration is the combination of the traction power supply system and battery bank. WINK vehicles will be operated in the northern Netherlands on the Leeuwarden-Groningen $r$ rail line, as well as in the provinces of Friesland and wnosi ponadto zaburzenie miejscowego krajobrazu. W artykule rozważa się techniczne, ekonomiczne i ekologiczne aspekty zwiększenia niewystarczającej drożności trasy i wprowadzenia zasobnikowych elektrycznych zespołów trakcyjnych do obsługi pasażerskiej na częściowo zelektryfikowanej linii w jednym z najbardziej atrakcyjnych turystycznie rejonów polskiego wybrzeża. Analizie poddano wybraną trasę Gdynia Główna - Hel charakteryzującą się bardzo wysokim obciążeniem ruchem turystycznym przebiegająca przez Półwysep Helski, który w całości objęty jest ochroną środowiska naturalnego $\mathrm{w}$ ramach programu Natura 2000 [20].

\section{WDRAŻANIE POJAZDÓW Z ZASOBNI- KAMI ENERGII W EUROPIE}

Rozwiązania takie zapoczątkowali Japończycy w 2007 r. wprowadzając do eksploatacji innowacyjny hybrydowy zespół trakcyjny NE-Train („New Energy Train"), w którym silnik Diesla zastapiony został silnikami elektrycznymi i baterią akumulatorów [1]. Po przeprowadzeniu serii testów do eksploatacji wprowadzony został zespół trakcyjny oznaczony EVE301, który w 2014 r. zaczął obsługiwać linię Utsunomiya - Karasuyama składającą się z dwóch odcinków, zelektryfikowanego o długości $11,7 \mathrm{~km}$ oraz niezelektryfikowanego o długości 20,4 km z 6 przystankami.

Jednocześnie w roku 2014 japoński koncern Hitachi zbudował zespół trakcyjny serii BEC819 z bateria akumulatorów o energii $380 \mathrm{kWh}$ i napięciu $1600 \mathrm{~V}$ [2]. Pojazd ten został wprowadzony do eksploatacji na niezelektryfikowanej linię Chikuhō o długości 10,8 km. W 2018 r. zespół serii BEC819 został wprowadzony do eksploatacji także na niezelektryfikowanej linii Kashii [3]. Zespół bliźniaczej konstrukcji serii EV-E801 wykorzystywany jest od marca 2017 r. na trasie obejmującej odcinek o długości $13,3 \mathrm{~km}$ zelektryfikowanej linii Ou oraz odcinek o długości $26,6 \mathrm{~km}$ niezelektryfikowanej linii Oga [4].

W 2015 r. w Wielkiej Brytanii przeprowadzone zostały pierwsze europejskie testy trakcyjnego pojazdu zasobnikowego o nazwie IPEMU (ang. Independently Powered Electric Multiple Unit). Pojazd ten zbudowany został na bazie elektrycznego zespołu Bombardier Electrostar klasy 379, zasilanego z sieci napięcia przemiennego $25 \mathrm{kV}, 50 \mathrm{~Hz}$, który wyposażono $\mathrm{w}$ baterię akumulatorów litowo-żelazowo-magnezowofosforanowych. Pojazd ten, testowany na trasie liczącej $15,1 \mathrm{~km}$ [5], choć ostatecznie nie wprowadzony do ruchu liniowego, zapoczątkował niemalże lawinowy rozwój takich rozwiązań w Europie.

W 2017 r. Stadler zaprezentował nowy pojazd o nazwie WINK, którego 18 egzemplarzy zamówił holenderski przewoźnik Arriva Netherlands. Pojazd ten wyposażony $\mathrm{w}$ elektryczne silniki napędowe może być skonfigurowany na trzy sposoby. Pierwszym z nich jest wykorzystanie konwencjonalnego silnika 
Groningen. Partial electrification of the LeeuwardenGroningen line is planned by 2025 , which will enable the replacement of combustion engines with battery accumulators with a total energy of $748 \mathrm{kWh}$. On the electrified part of the rail line, the vehicle will be powered from the $1.5 \mathrm{kV}$ DC catenary line. In this part of the line, batteries will also be charged, which will be used to power the vehicle in the nonelectrified part. Delivery of all 18 ordered vehicles is to take place by the end of $2020[10,11]$.

The second vehicle from Stadler is the Flirt Akku, presented in 2018. It was created by equipping the Flirt with electric drive with a battery. This vehicle is capable of covering a distance of $80 \mathrm{~km}$ on battery power. The maximum speed of the Flirt Akku team is $140 \mathrm{~km} / \mathrm{h}$. It takes 15-20 minutes to fully charge the batteries from the catenary [12]. In 2019, Stadler won a tender for the supply of 55 Flirt Akku multiple units to the federal state of Schleswig-Holstein in northern Germany. These teams are to support, among others non-electrified Kiel-Lübeck railway route. German media reports that the deliveries of all vehicles are to end in 2022 [13]. Siemens Mobility and the Austrian Federal Railways (OBB) presented in 2018 a new traction vehicle, the Desiro ML Cityjet Eco. It was created as part of the Austrian program for the complete elimination of diesel units from the domestic rolling stock by 2035 . The unit can be powered by an alternating voltage of $15 \mathrm{kV}$ or $25 \mathrm{kV}$ to power the unit on electrified sections of the line. In non-electrified sections, the vehicle is powered by a lithium-titanate battery with an energy of $528 \mathrm{kWh}$ [14]. The unit is drived by four induction motors with a total power of $2600 \mathrm{~kW}$, which allows it to develop a maximum speed of $140 \mathrm{~km} / \mathrm{h}$ [15]. In the first months of 2020, passenger tests were carried out on railway lines near Vienna, constituting the last stage of preparations for putting the trains into service [16]. In September 2018, Bombardier unveiled a multiple unit called Talent 3, built in cooperation with the German government, which intends to eliminate diesel units from use in Germany by 2030, currently serving $40 \%$ of German lines. The overhead contact line of $15 \mathrm{kV}$ alternating voltage and a frequency of 16.7 $\mathrm{Hz}$ is used to power the vehicle on the electrified sections. The maximum speed of the vehicle is 160 $\mathrm{km} / \mathrm{h}$. Using battery power on non-electrified sections, the vehicle can travel $40 \mathrm{~km}$ and ultimately $100 \mathrm{~km}[17,18]$. The first recipient of the vehicle is the Austrian Federal Railways (OBB), which in 2016 signed a contract for the supply of 300 Talent 3 units

[19]. Under this contract, 46 teams have already been commissioned in 2020. One of the latest solutions in this field is Alstom Coradia Continental BEMU with battery-traction drive. A battery of high-voltage lithium-ion batteries installed on the roof will allow it to cover a distance of $120 \mathrm{~km}$ on battery power. The wysokoprężnego zasilanego olejem napędowym lub uwodornionym olejem roślinnym (HVO). Pojazd wyposażony może być również w napęd hybrydowy składający się $\mathrm{z}$ silnika spalinowego napędzającego prądnice i układu zasilania trakcyjnego. Ostatnią, najbardziej przyjazną środowisku konfiguracją napędu jest połaczenie układu zasilania trakcyjnego oraz baterii akumulatorów. Pojazdy WINK eksploatowane będą w północnej Holandii na trasie LeeuwardenGroningen, a także w prowincjach Fryzja oraz Groningen. Planowana jest częściowa elektryfikacja trasy Leeuwarden-Groningen do 2025 r., co umożliwi zastapienie silników spalinowych zasobnikami akumulatorowymi o łącznej energii-748 kWh. Na zelektryfikowanej części trasy pojazd zasilany będzie $\mathrm{z}$ sieci trakcyjnej napięcia stałego $1,5 \mathrm{kV}$. W tej cześci trasy ładowane będą także akumulatory, które służyć będą zasilaniu pojazdu w części niezelektryfikowanej. Dostarczenie wszystkich 18 zamówionych pojazdów nastąić ma do końca 2020 r. [6, 7].

Drugim pojazdem firmy Stadler jest Flirt Akku zaprezentowany w 2018 r. Powstał on w wyniku wyposażenia modelu Flirt o napędzie elektrycznym w baterię akumulatorów. Pojazd ten zdolny jest do pokonania dystansu $80 \mathrm{~km}$ na zasilaniu bateryjnym. Prędkość maksymalna zespołu Flirt Akku wynosi $140 \mathrm{~km} / \mathrm{h}$. Pełne ładowanie akumulatorów z sieci trakcyjnej trwa 15-20 minut [8]. W 2019 r. Stadler wygrał przetarg na dostawę 55 zespołów trakcyjnych Flirt Akku do kraju związkowego Szlezwik-Holsztyn w północnych Niemczech. Zespoły te mają obsługiwać m.in. niezelektryfikowaną trasę Kilonia-Lubeka. Niemieckie media informują, że dostawy wszystkich pojazdów zakończyć mają się w 2022 r. [9].

Siemens Mobility oraz Austriackie koleje Federalne (OBB) zaprezentowały w 2018 r. nowy pojazd trakcyjny o nazwie Desiro ML Cityjet Eco. Powstał on w ramach austriackiego programu całkowitego wyeliminowania z krajowego taboru kolejowego zespołów spalinowych do 2035 r. Do zasilania zespołu na zelektryfikowanych odcinkach linii wykorzystywana może być sieć trakcyjna o napięciu przemiennym $15 \mathrm{kV}$ lub $25 \mathrm{kV}$. Na odcinkach niezelektryfikowanych pojazd zasilany jest $\mathrm{z}$ baterii akumulatorów litowotytanowych o energii $528 \mathrm{kWh}$ [10]. Zespół napędzają cztery silniki indukcyjne o łącznej mocy $2600 \mathrm{~kW}$, co pozwala na rozwinięcie maksymalnej prędkości wynoszącej $140 \mathrm{~km} / \mathrm{h}$ [11]. W pierwszych miesiącach 2020 r. na liniach kolejowych w okolicach Wiednia przeprowadzono testy $\mathrm{z}$ udziałem pasażerów, stanowiące ostatni etap przygotowań do wprowadzenia pociągów do eksploatacji [12].

We wrześniu 2018 r. Bombardier zaprezentował zespół trakcyjny o nazwie Talent 3 zbudowany przy współpracy z niemieckim rządem, który zamierza do 2030 r. wyeliminować z użytku w Niemczech zespoły spalinowe, obsługujące obecnie $40 \%$ niemieckich 
vehicle is to reach a top speed of $160 \mathrm{~km} / \mathrm{h}$. At the beginning of 2020, Alstom signed a contract for the supply of 11 units to operate the non-electrified 80 $\mathrm{km}$ route Chemnitz - Leipzig. The new vehicles are to be put into service in 2023 [17].

\section{INVENTORY OF THE ROUTE GDYNIA GLÓWNA STATION - HEL STATION}

\subsection{Data for theoretical passage}

The analyzed route runs along two lines. The first is line 202, part of which is an electrified section of the analyzed route, $14.543 \mathrm{~km}$ long, connecting the Gdynia Główna station with the Reda station. The second part of the route is the non-electrified line 213, $61.669 \mathrm{~km}$ long, connecting the Reda station with the Hel station. In total, the Gdynia Główna - Hel route is $76.212 \mathrm{~km}$ long. There are 17 stops on the route under analysis, 14 of which are on the non-electrified section. Figure 1 shows the course of the analyzed route.

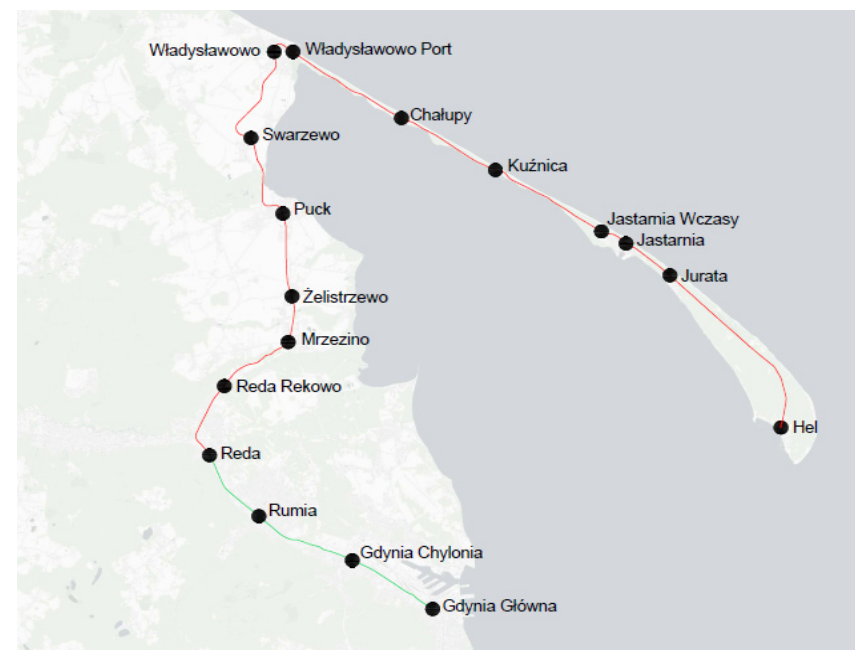

Fig. 1. The course of the Gdynia Główna station- Hel station route (own elaboration)

Rys. 1. Przebieg trasy Gdynia Główna - Hel (opracowanie własne)

On the single-track line 213 , it is possible to pass vehicles at the stations Mrzezino, Puck, Władysławowo, Kuźnica and Jastarnia. Depending on the vehicle course, it is carried out at one, two or three of the above-mentioned stations. Calculations of the theoretical passage were made based on the data of the summer timetable of vehicles of the POLREGIO carrier Gdynia Główna - Hel. For the purposes of the calculations, a relative timetable of regional vehicles in the summer season was developed, presented for one direction in Table 1. This timetable takes into account the stop at all stations on the route. In the direction of Hel, there are two turnputs (in Puck and Kuźnica), and the entire journey takes $1 \mathrm{~h} 53 \mathrm{~min}$. The drive to Gdynia Główna takes 2 h 9 min, and the passing vehicles are carried out at the Jastarnia, Władysławowo and Mrzezino stations. linii. Do zasilania pojazdu na odcinkach zelektryfikowanych wykorzystywana jest sieć trakcyjna napięcia przemiennego $15 \mathrm{kV}$ i częstotliwości $16,7 \mathrm{~Hz}$. Maksymalna prędkość pojazdu wynosi $160 \mathrm{~km} / \mathrm{h}$. Przy wykorzystaniu zasilania bateryjnego na odcinkach niezelektryfikowanych pojazd może przejechać $40 \mathrm{~km}$ i docelowo $100 \mathrm{~km}[13,14]$. Pierwszym odbiorca pojazdu sa Austriackie koleje Federalne (OBB), które w 2016 r. podpisały umowę na dostawę 300 zespołów Talent 3 [15]. W ramach tej umowy w 2020 r. oddano już do użytku 46 zespołów.

Jednym $\mathrm{z}$ najnowszych rozwiązań $\mathrm{w}$ tej dziedzinie jest Alstom Coradia Continental BEMU o napędzie trakcyjno-akumulatorowym. Zainstalowana na dachu bateria wysokonapięciowych akumulatorów litowojonowych pozwoli ma na pokonanie dystansu $120 \mathrm{~km}$ na zasilaniu bateryjnym. Pojazd osiagać ma prędkość maksymalną wynoszącą $160 \mathrm{~km} / \mathrm{h}$. Na początku 2020 r. Alstom podpisał umowę na dostawę 11 zespołów do obsługi niezelektryfikowanej trasy Chemnitz Lipsk o długości $80 \mathrm{~km}$. Nowe pojazdy oddane zostać mają do użytku w 2023 r. [17].

\section{INWENTARYZACJA TRASY GDYNIA GLÓWNA - HEL}

\subsection{Dane do przejazdu teoretycznego}

Trasa poddana analizie przebiega dwoma liniami. Pierwszą z nich jest linia 202, której częścią jest zelektryfikowany odcinek analizowanej trasy o długości $14,543 \mathrm{~km}$ łączący stację Gdynia Główna ze stacją Reda. Drugim fragmentem trasy jest niezelektryfikowana linia 213 o długości $61,669 \mathrm{~km}$, łącząca stacje Reda ze stacją Hel. Łącznie analizowana trasa Gdynia Główna - Hel liczy 76,212 km. Na analizowanej trasie znajduje się 17 przystanków, z czego 14 na odcinku niezelektryfikowanym. Rysunek 1. przedstawia przebieg analizowanej trasy.

$\mathrm{Na}$ jednotorowej linii 213 mijanie się pojazdów możliwe jest na stacjach Mrzezino, Puck, Władysławowo, Kuźnica oraz Jastarnia. W zależności realizowanego kursu pojazdów realizowane jest ono na jednej, dwóch lub trzech z wymienionych stacji. Obliczenia przejazdu teoretycznego wykonano w oparciu o dane letniego rozkładu jazdy pojazdów przewoźnika POLREGIO relacji Gdynia Główna - Hel. Na potrzeby obliczeń opracowano względny rozkład jazdy pojazdów regionalnych $w$ sezonie letnim przedstawiony dla jednego kierunku w tablicy 1. Rozkład ten uwzględnia postój na wszystkich stacjach na trasie. W kierunku Helu realizowane są dwie mijanki (w miejscowości Puck oraz Kuźnica), a cały przejazd trwa 1 h 53 min. Przejazd w kierunku Gdyni Głównej trwa 2 h 9 min, a mijanie się pojazdów realizowane jest na stacjach Jastarnia, Władysławowo oraz Mrzezino.

Niezbędne do przeprowadzenia obliczeń lokalnych oporów ruchu wykonywanych $\mathrm{w}$ ramach obliczeń przejazdu teoretycznego dane dotyczące nachylenia trasy opracowano na podstawie oficjalnego profilu 
The data on the slope of the route necessary to calculate the local movement resistances to the traffic performed as part of the theoretical passage calculations was prepared on the basis of the official Gdynia Główna - Hel route profile. The resultant inclination is shown in Fig. 2.

Relative summer timetable of regional trains on the Gdynia Glówna station- Hel route Table 1

Względny letni rozkład jazdy pociągów regionalnych na trasie Gdynia Glówna - Hel Tablica 1

\begin{tabular}{|c|c|c|c|c|}
\hline Line & $\begin{array}{l}\text { Kilometer } \\
\text { of line }\end{array}$ & $\begin{array}{l}\text { Kilometer } \\
\text { of rout }\end{array}$ & Station & $\begin{array}{l}\text { Stopover } \\
\text { time [s] }\end{array}$ \\
\hline \multirow{3}{*}{202} & 20,992 & 0 & Gdynia Główna & 30 \\
\hline & 26,174 & 5.182 & Gdynia Chylonia & 30 \\
\hline & 31,849 & 10.857 & Rumia & 30 \\
\hline \multirow{14}{*}{213} & 0 & 14.543 & Reda & 30 \\
\hline & 4,758 & 19.301 & Reda Rekowo & 30 \\
\hline & 8,852 & 23.395 & Mrzezino & 30 \\
\hline & 11,367 & 25.91 & Żelistrzewo & 30 \\
\hline & 15,986 & 30.529 & Puck & 840 \\
\hline & 20,97 & 35.513 & Swarzewo & 30 \\
\hline & 26,718 & 41.261 & Władysławowo & 300 \\
\hline & 28,269 & 42.812 & $\begin{array}{l}\text { Władysławowo } \\
\text { Port } \\
\end{array}$ & 30 \\
\hline & 34,73 & 49.273 & Chałupy & 30 \\
\hline & 40,391 & 54.934 & Kuźnica & 480 \\
\hline & 46,375 & 60.918 & Jastarnia Wczasy & 30 \\
\hline & 48,024 & 62.567 & Jastarnia & 30 \\
\hline & 51,014 & 65.557 & Jurata & 30 \\
\hline & 61,669 & 76.212 & Hel & 30 \\
\hline & & & Total travel time & $1 \mathrm{~h} 53 \mathrm{~min}$ \\
\hline
\end{tabular}

\subsection{Technical condition of stations and stops as well as field possibilities of building new pass- ing loops}

As part of the inventory of the analyzed route, the technical condition of the stations and stops located on non-electrified line 213 was reviewed. In 20122015 , the line underwent a thorough modernization, under which all stations and stops were equipped with high platforms, standardized shelters, timetable boards and places parking for bicycles.

The single-track line 213 running from Reda to Hel has been struggling with the problem of limited capacity for many years. In the summer season, when the line is particularly busy with tourist traffic, the stopping time at the passing loops for regional trains is even 17 minutes. A minimalist way to solve the problem of limited line capacity is to build new staggered tracks along the route.

Based on the analysis of the vehicle stopping time on the existing passing loops, the space available for the construction of the staggered track and the distance trasy Gdynia Główna - Hel. Wypadkowe pochylenie przedstawiono na rys. 2 .

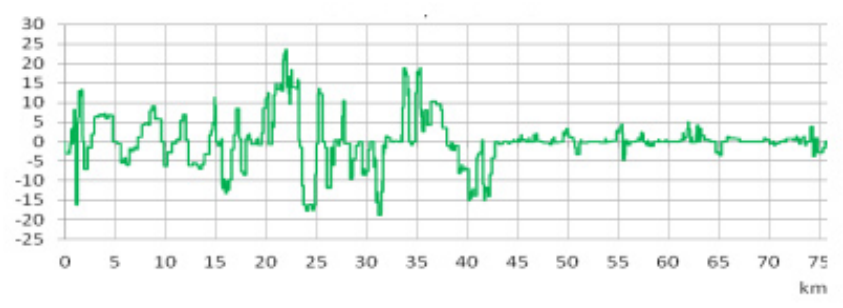

Fig. 2. The resultant inclination on het route Gdynia Główna $\mathrm{Hel}$

Rys. 2. Pochylenie wypadkowe na trasie Gdynia Główna - Hel

\subsection{Stan techniczny stacji i przystanków oraz tere- nowe możliwości budowy nowych mijanek}

W ramach inwentaryzacji analizowanej trasy dokonano przeglądu stanu technicznego stacji i przystanków znajdujących się na niezelektryfikowanej linii 213. Linia ta przeszła w latach 2012-2015 gruntowną modernizację, w ramach której wszystkie stacje i przystanki wyposażone zostały w wysokie perony, ustandaryzowane wiaty, tablice rozkładowe oraz miejsca postojowe dla rowerów.

Jednotorowa linia 213 biegnąca $z$ Redy do Helu od wielu lat boryka się z problemem ograniczonej przepustowości. W sezonie letnim, gdy linia ta jest szczególnie obciążona ruchem turystycznym, czas postoju pociagów regionalnych na mijankach wynosi nawet 17 minut. Minimalistycznym sposobem rozwiązania problemu ograniczonej przepustowości linii jest budowa nowych mijanek na trasie.

Na podstawie przeprowadzonej analizy czasu postoju pojazdów na obecnie istniejących mijankach, dostępnej przestrzeni na budowę toru mijankowego oraz odległości pomiędzy przystankami sugeruje się budowę nowych mijanek na przystankach Reda Rekowo, Żelistrzewo, Swarzewo, Chałupy oraz Jurata. Budowa mijanki na przystanku Reda Rekowo wiąże się z koniecznością zmiany przebiegu ulicy Sosnowej. Na przystanku Żelistrzewo budowa toru mijankowego możliwa jest bez modernizacji obecnie istniejącej infrastruktury drogowej oraz obiektów budowlanych. Utworzenie mijanki na przystanku Swarzewo z powodu bliskiego położenia peronu oraz budynku nieczynnego dworca kolejowego wiąże się z koniecznością budowy dodatkowego peronu jednokrawędziowego do obsługi toru mijankowego. $\mathrm{Na}$ przystanku Chałupy utworzenie mijanki stwarza konieczność wyburzenia lokalu gastronomicznego znajdującego się w obszarze proponowanego toru mijankowego. W miejscowości Jurata ze względu na gęstą zabudowę po jednej ze stron linii można rozważyć budowę nowego peronu dwu-krawędziowego oraz wykorzystanie dostępnej przestrzeni leśnej na budowę toru mijankowego.

Rysunki 3 - 7 przedstawiają proponowane umiejscowienie nowych mijanek na przystankach. Kolorem 
between the stops, it is suggested to build new turnout routes at the Reda Rekowo, Żelistrzewo, Swarzewo, Chałupy and Jurata stops. Building a staggered track czerwonym zaznaczono proponowaną lokalizację toru mijankowego, kolorem niebieskim - proponowaną lokalizację nowych peronów.

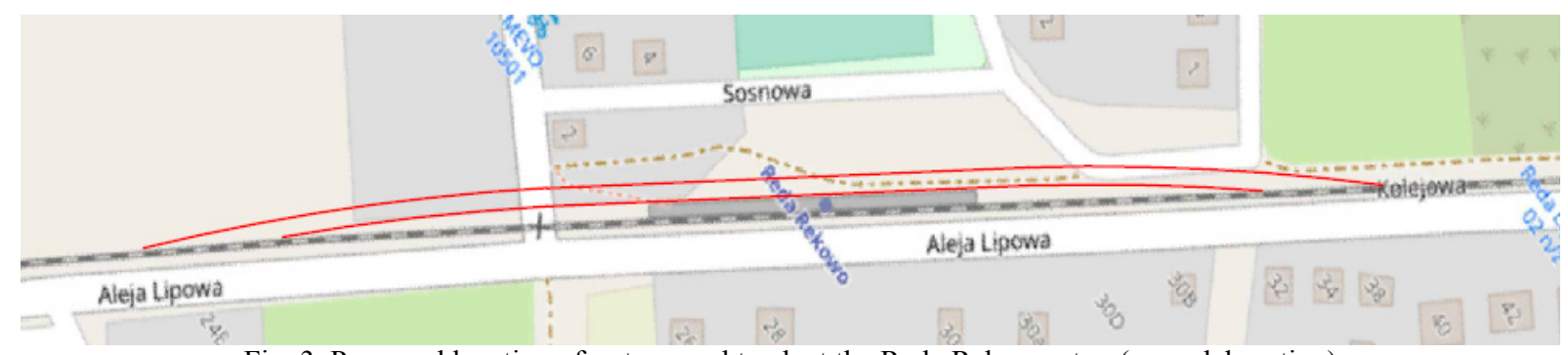

Fig. 3. Proposed location of a staggered track at the Reda Rekowo stop (own elaboration)

Rys. 3. Proponowana lokalizacji mijanki na przystanku Reda Rekowo (opracowanie własne)

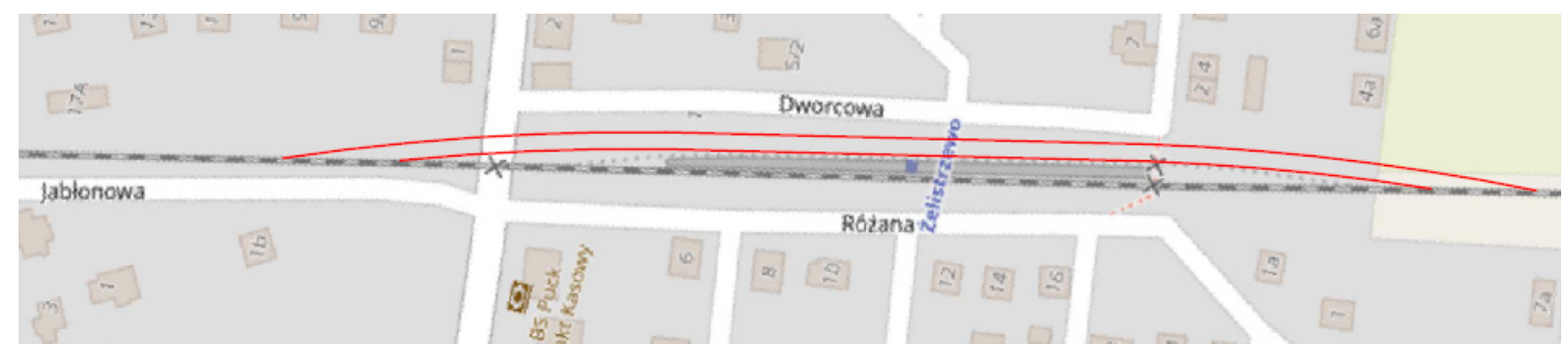

Fig. 4. Proposed location of a staggered track at the Żelistrzewo stop (own elaboration)

Rys. 4. Proponowana lokalizacji mijanki na przystanku Żelistrzewo (opracowanie własne)

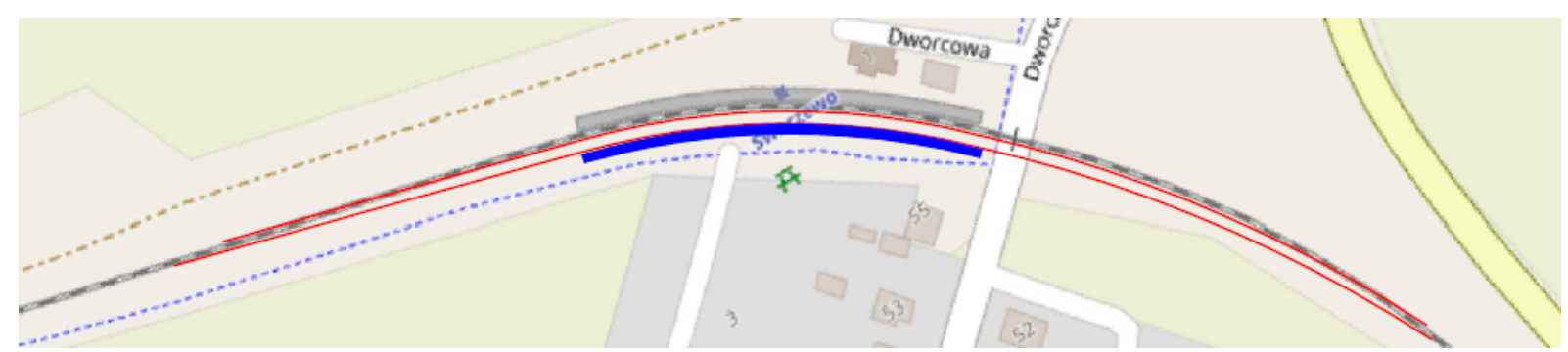

Fig. 5. Proposed location of a staggered track at the Swarzewo stop (own elaboration)

Rys. 5. Proponowana lokalizacji mijanki na przystanku Swarzewo (opracowanie własne)

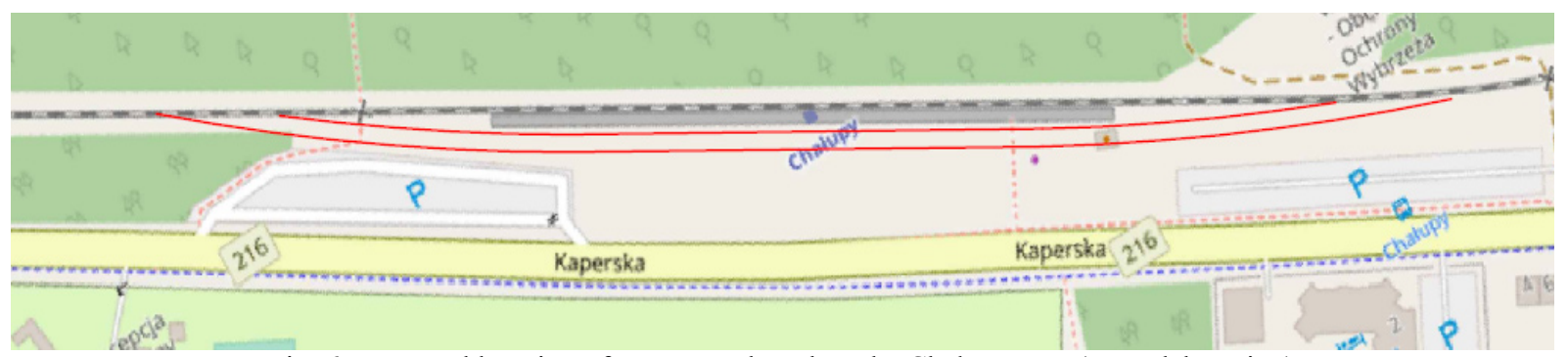

Fig. 6. Proposed location of a staggered track at the Chałupy stop (own elaboration)

Rys. 6. Proponowana lokalizacji mijanki na przystanku Chałupy (opracowanie własne)

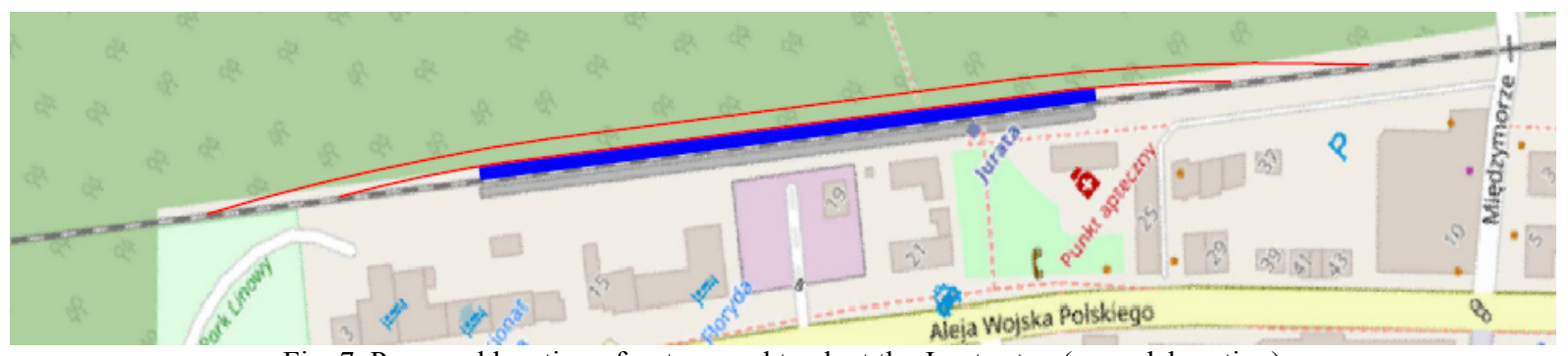

Fig. 7. Proposed location of a staggered track at the Jurata stop (own elaboration)

Rys .7. Proponowana lokalizacji mijanki na przystanku Jurata (opracowanie własne) 
at the Reda Rekowo stop requires changing the route of Sosnowa Street. At the Żelistrzewo stop, the construction of the staggered track is possible without modernizing the existing road infrastructure and building structures. The creation of a staggered track at the Swarzewo stop due to the proximity of the platform and the building of the closed railway station is associated with the need to build an additional single-edge platform to support the staggered track. At the Chałupy stop, creating a passing loop track makes it necessary to demolish the restaurant located in the area of the proposed passing loop. In Jurata, due to the dense development on one side of the line, it is possible to consider building a new two-edge platform and using the available forest space to build a passing loop track.

Figures $3-7$ show the proposed locations of new staggered tracks at stops. The proposed location of the passing loops is marked in red, while the proposed location of new platforms is marked in blue.

\section{ENERGY DEMAND ON THE NON- ELECTRIFIED SECTION REDA - HEL}

4.1. Parameters of the traction multiple units used in the calculations

To calculate the energy demand on the non-electrified section Reda - Hel, the technical parameters of an exemplary Stadler Flirt multiple unit presented in Table 2 were used. The values of technical parameters that were not provided by the vehicle manufacturer were adopted on the basis of the data presented in [19].

\subsection{Traction characteristic curve}

The traction characteristic curve show the relationship between the maximum traction force and the vehicle speed. When the manufacturer does not provide the traction curve characteristic of the vehicle, its basic parameters may be used to determine it [19]:

- total power of traction motors

- initial start-up acceleration value

- maximum vehicle speed.

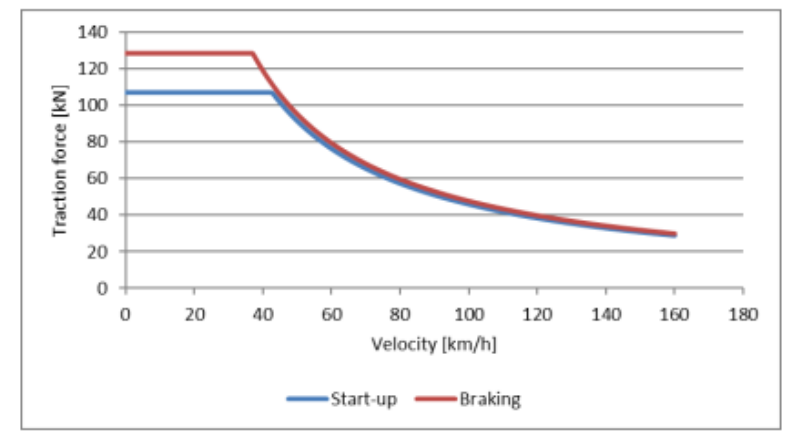

Fig. 8. Traction characteristic curve for start-up and braking of the multiple unit Stadler Flirt

Rys. 8. Charakterystyka trakcyjna i hamowania elektrycznego zespołu trakcyjnego Stadler Flirt
4. ZAPOTRZEBOWANIE ENERGETYCZNE NA ODCINKU NIEZELEKTRYFIKOWANYM REDA - HEL

4.1. Parametry zespołu trakcyjnego zastosowanego w obliczeniach

Do przeprowadzenia obliczeń zapotrzebowania energetycznego na niezelektryzowanym odcinku Reda Hel posłużono się parametrami technicznymi przykładowego zespołu trakcyjnego Stadler Flirt przedstawionymi $\mathrm{w}$ tablicy 2 . Wartości parametrów technicznych, które nie zostały udostępnione przez producenta zespołu zostały przyjęte na podstawie danych przedstawionych $\mathrm{w}[19]$.

Technical data of the Stadler Flirt multiple unit [18] Table 2

Dane techniczne zespołu trakcyjnego Stadler Flirt [18] Tablica 2

\begin{tabular}{|l|l|}
\hline Number of segments & 2 \\
\hline Service weight & $76 \mathrm{t}$ \\
\hline $\begin{array}{l}\text { Service weight with power stor- } \\
\text { age }\end{array}$ & $96 \mathrm{t}$ \\
\hline Total number of seats & 219 \\
\hline Vehicle length & $42066 \mathrm{~mm}$ \\
\hline Maximum motors power & $1300 \mathrm{~kW}$ \\
\hline Maximum speed & $140 \mathrm{~km} / \mathrm{h}$ \\
\hline Accelerate the start up & $0.83 \mathrm{~m} / \mathrm{s}^{2}$ \\
\hline \hline Liczba członów & 2 \\
\hline Układ osi & Bo'2’2 \\
\hline Masa służbowa & $76 \mathrm{t}$ \\
\hline Masa służbowa z zasobnikiem & $96 \mathrm{t}$ \\
\hline Całkowita liczba miejsc & 219 \\
\hline Długość pojazdu & $42066 \mathrm{~mm}$ \\
\hline Maksymalna moc silników & $1300 \mathrm{~kW}$ \\
\hline Prędkość maksymalna & $140 \mathrm{~km} / \mathrm{h}$ \\
\hline Przyśpieszenie rozruchu & $0,83 \mathrm{~m} / \mathrm{s}^{2}$ \\
\hline
\end{tabular}

\subsection{Charakterystyka trakcyjna}

Charakterystyka trakcyjna przedstawia zależność maksymalnej siły pociagowej od prędkości pojazdu. W przypadku gdy producent nie udostępnia charakterystyki trakcyjnej pojazdu, do jej wyznaczenia wykorzystane mogą być podstawowe jego parametry [19]:

- całkowita moc silników trakcyjnych

- wartość przyśpieszenia początkowego rozruchu

- masa całkowita pojazdu

- prędkość maksymalna pojazdu.

Wykreślając charakterystykę trakcyjną wyróżnić w niej można dwa obszary. Pierwszym z nich jest obszar pracy ze stałą siłą pociagową, drugim zaś obszarem pracy ze stałą mocą.

W celu wyznaczenia charakterystyki hamowania przyjęto opóźnienie początkowe hamowania większe o $20 \%$ od przyśpieszenia początkowego rozruchu. Wyznaczone charakterystyki przedstawia rysunek 8 . 
Two areas can be distinguished in the traction characteristic curve. The first is the area of work with constant traction force, the second is the area of work with constant force. In order to determine the braking characteristics, the initial deceleration of braking greater by $20 \%$ than the initial acceleration of the start was assumed. The determined curve is shown in Figure 8.

$$
\frac{d v}{d t}=\frac{F(v)-W(v, s)}{m \cdot k}
$$

where:

$$
\begin{aligned}
& d v \quad-\text { velocity increase }[\mathrm{m} / \mathrm{s}], \\
& d t \quad-\text { time increase }[\mathrm{s}], \\
& F(v) \quad-\text { traction effort dependent on driving } \\
& \text { speed }[\mathrm{N}], \\
& W(v, s) \quad-\text { total resistance to motion depending on } \\
& \text { the driving speed and current position }[\mathrm{N}], \\
& m \quad-\text { vehicle mass }[\mathrm{kg}], \\
& \begin{array}{l}
k \\
k
\end{array} \\
& \quad \text { rotating mass factor (for multiple units } \\
& \text { k }=1,15)
\end{aligned}
$$

The total resistance to vehicle motion consists of local and basic resistance. Local resistances are related to the topography. The main resistance to motion results from the aerodynamic forces depending on the square of the vehicle speed. They also take into account the resistance linearly dependent on the speed (including the work of shock absorbers), and the resistance independent of the speed related to rolling friction and friction in wheel bearings. The resistance to movement for Polish passenger teams is determined by the relationship:

$$
\begin{gathered}
W_{z}=(0.65+0.054 \cdot v) \cdot Q_{z}+147 \cdot n_{o z}+ \\
\left(2.7+n_{z}\right) \cdot 1.271 \cdot v^{2}
\end{gathered}
$$

where:

$W_{z}$ - fundamental resistance to movement [N],

$Q_{z}$ - traction unit pressure on the track $[\mathrm{kN}]$,

$n_{o z}$ - number of axles of the train-set [-],

$n_{z}$ - number of units of a train-set [-].

The driving time and the distance travelled by the vehicle are calculated by summing the time and distance increments, respectively, counted from the beginning of the simulation:

$$
\begin{aligned}
& t_{n}=\sum_{0}^{n} \Delta t_{i} \\
& s_{n}=\sum_{0}^{n} \Delta s_{i}
\end{aligned}
$$

where:

$t_{n} \quad-$ driving time to the $\mathrm{n}^{\text {th }}$ calculation step [s],

$S_{n} \quad$ - path travelled to the $\mathrm{n}^{\text {th }}$ calculation step [m],

$\Delta t_{i}$ - time increment in the i-th calculation step [s],

$\Delta s_{i}$ - speed increase in the i-th calculation step [m/s].

\subsection{Przejazd teoretyczny}

Do przeprowadzenia obliczeń przejazdu teoretycznego zaimplementowano zaproponowany w [19] model obliczeń. Zastosowano uproszczenie modelu pojazdu do punktu materialnego o określonej masie oraz brak fazy wybiegu podczas przejazdu. Obliczenia przejazdu teoretycznego opierają się na równaniu ruchu pojazdu wyrażonego wzorem (1). Symulacji przejazdu teoretycznego dokonuje się poprzez odpowiednie modyfikacje wartości przyrostu prędkości pojazdu w zależności od fazy ruchu pojazdu.

$$
\frac{d v}{d t}=\frac{F(v)-W(v, s)}{m \cdot k}
$$

gdzie:

$d v \quad$ - przyrost prędkości $[\mathrm{m} / \mathrm{s}]$,

$d t \quad$ - przyrost czasu [s],

$F(v)$ - siła pociagowa zależna od prędkości jazdy

$[\mathrm{N}]$,

$W(v, s) \quad$ - całkowite opory ruchu zależne od prędkości jazdy i bieżącego położenia [N],

$m$ - masa pojazdu [kg],

$k-$ współczynnik mas wirujących (dla zespołów trakcyjnych $\mathrm{k}=1,15$ ).

$\mathrm{Na}$ całkowite oporu ruchu pojazdu składają się opory lokalne oraz zasadnicze. Opory lokalne związane są z ukształtowaniem terenu. Zasadnicze opory ruchu wynikają $\mathrm{z}$ aerodynamicznych sił zależnych od kwadratu prędkości pojazdu. Uwzględniają one także opory zależne liniowo od prędkości (m.in. pracę amortyzatorów), oraz opory niezależne od prędkości związane $\mathrm{z}$ tarciem tocznym oraz tarciem w łożyskach kół. Opory ruchu dla polskich zespołów pasażerskich określone są zależnością:

$$
\begin{gathered}
W_{z}=(0.65+0.054 \cdot v) \cdot Q_{z}+147 \cdot n_{o z}+ \\
\left(2.7+n_{z}\right) \cdot 1.271 \cdot v^{2}
\end{gathered}
$$

gdzie:

$W_{z}$ - zasadnicze opory ruchu [N],

$Q_{z}$ - nacisk zespołu trakcyjnego na tor [kN],

$n_{o z}-$ liczba osi zespołu trakcyjnego [-],

$n_{z}$ - liczba członów zespołu trakcyjnego [-].

Czas jazdy oraz droge przebytą przez pojazd oblicza się poprzez zsumowanie odpowiednio przyrostów czasu oraz drogi, liczonych od początku symulacji:

$$
t_{n}=\sum_{0}^{n} \Delta t_{i}
$$

$$
s_{n}=\sum_{0}^{n} \Delta s_{i}
$$

gdzie:

$t_{n}$ - czas jazdy do $n$-tego kroku obliczeniowego [s],

$S_{n}$ - droga przebyta do $n$-tego kroku obliczeniowego $[\mathrm{m}]$,

$\Delta t_{i}$ - przyrost czasu w $i$-tym kroku obliczeniowym [s], $\Delta s_{i}$ - przyrost prędkości w $i$-tym kroku obliczeniowym $[\mathrm{m} / \mathrm{s}]$. 
The calculations assume the times of stopping at stops resulting from the summer timetable of regional trains. After performing the calculations according to the formula (3) and (4), the waveforms presented in Figures 9 and 10 were obtained.

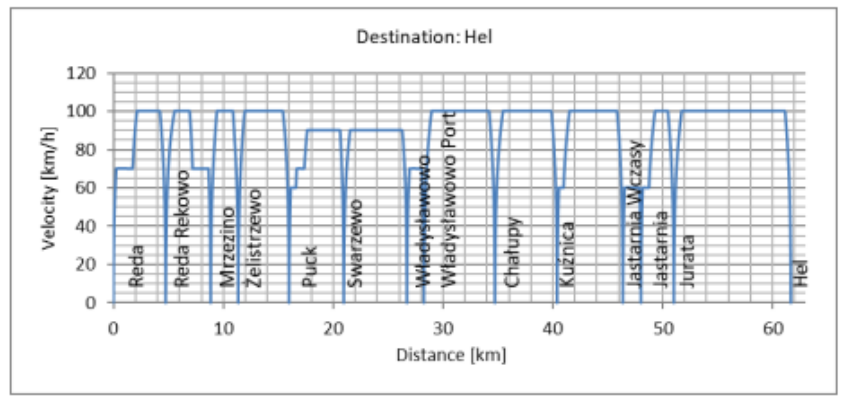

Fig. 9. Vehicle speed as a function of the road on the route Reda Hel

Rys. 9. Prędkość pojazdu w funkcji drogi na trasie Reda - Hel

\subsection{Energy balance}

Calculations of the energy balance of the trip were carried out simultaneously with the calculation of the distance covered by the vehicle and the time of the trip. The energy balance for the non-electrified section of the Reda - Hel route was calculated as the difference between the energy consumed by the vehicle and the energy recovered as a result of braking.

The vehicle's energy requirement consists of two parts. The first is traction needs, which are the energy consumed by traction motors to drive the vehicle. The second part of the energy demand is non-traction needs, including air conditioning, heating, lighting and control circuits. In the calculations of the energy balance it was assumed that the power of non-traction needs constitutes $10 \%$ of the traction power of the vehicle annually. The on-board voltage of the vehicle of $2000 \mathrm{~V}$ was assumed for the calculations.

The current of the traction needs of a vehicle equipped with a drive system with an power electronic converter is expressed in the relationship:

where:

$$
I_{t n}=\frac{F\left(v_{s} r\right)_{n} \cdot v_{s} r n}{U_{n} \cdot \eta_{w}}
$$

$I_{t n} \quad-$ current of the traction needs in the $\mathrm{n}^{\text {th }}$ step of calculation [A],

$F\left(v_{s r}\right)_{n}$ - traction force or regenerative braking force dependent on the vehicle speed in the $\mathrm{n}^{\text {th }}$ calculation step $[\mathrm{N}]$,

$v_{s r n} \quad-$ average speed at a given step in the $\mathrm{n}^{\text {th }}$ calculation step $[\mathrm{m} / \mathrm{s}]$,

$\eta_{w} \quad-$ the resultant efficiency of the system $\left(\eta_{w}\right.$ $=0.86$ ).

The efficiency of individual elements of the system was adopted on the basis of [19]:
W obliczeniach przyjęto czasy postoju na przystankach wynikające $\mathrm{z}$ letniego rozkładu jazdy pociągów regionalnych. Po wykonaniu obliczeń według wzoru (3) i (4) uzyskano, między innymi, przebiegi przedstawione na rysunkach 9 i 10 .

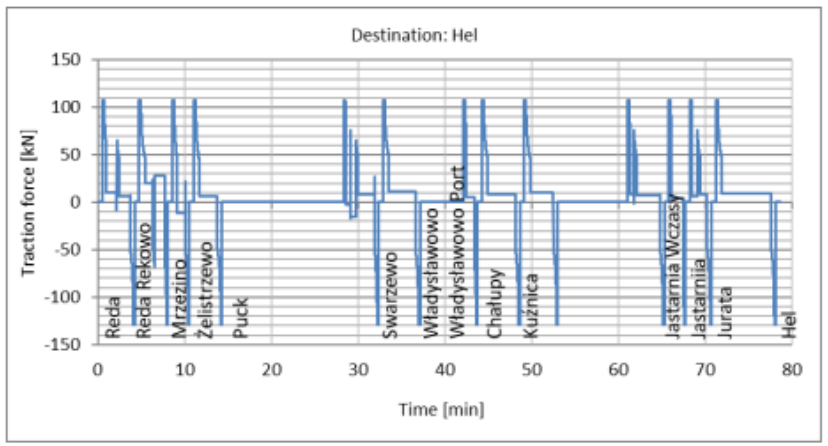

Fig. 10. Diagram of traction force of the vehicle on the route Reda $-\mathrm{Hel}$

Rys. 10. Wykres siły pociagowej pojazdu na trasie Reda - Hel

\subsection{Bilans energetyczny}

Obliczenia bilansu energetycznego przejazdu przeprowadzone zostały jednocześnie $\mathrm{z}$ obliczeniami przebytej przez pojazd drogi i czasu przejazdu. Bilans energetyczny dla niezelektryfikowanego odcinka trasy Reda - Hel obliczony został jako różnica pomiędzy energią pobraną przez pojazd i odzyskaną w skutek hamowania.

Zapotrzebowanie energetyczne pojazdu składa się z dwóch części. Pierwszą z nich są potrzeby trakcyjne, które stanowią energię pobieraną przez silniki trakcyjne w celu napędzania pojazdu. Drugą z części zapotrzebowania energetycznego są potrzeby nietrakcyjne, w tym m.in. klimatyzacja, ogrzewanie, oświetlenie oraz obwody sterownicze. W obliczeniach bilansu energetycznego przyjęto, że moc potrzeb nietrakcyjnych stanowi średnio-rocznie $10 \%$ mocy trakcyjnej pojazdu. Do obliczeń przyjęto hipotetycznie napięcie pokładowe pojazdu $2000 \mathrm{~V}$.

Prąd potrzeb trakcyjnych pojazdu wyposażonego $\mathrm{w}$ układ napędowy z przekształtnikiem energoelektronicznym wyrażony jest zależnością:

$$
I_{t n}=\frac{F\left(v_{s r}\right)_{n} \cdot v_{s r n}}{U_{n} \cdot \eta_{w}}
$$

gdzie:

$I_{t n}-$ prąd potrzeb trakcyjnych w n-tym kroku obliczeniowym [A],

$F\left(v_{s r}\right)_{n}$ - siła pociagowa lub siła hamowania odzyskowego zależna od prędkości pojazdu w ntym kroku obliczeniowym [N],

$v_{s r n}$ - prędkość średnia $\mathrm{w}$ danym kroku w n-tym kroku obliczeniowym [m/s],

$\eta_{w}$ - wypadkowa sprawność układu $\left(\eta_{w}=0,86\right)$ $[-]$.

Sprawności poszczególnych elementów układu, przyjęto na podstawie [19]: 
$\eta_{p}-$ mechanical transmission efficiency $\left(\eta_{p}=\right.$ $0.98)$,

$\eta_{s}$ - the efficiency of the traction motor $\left(\eta_{\mathrm{s}}=\right.$ $0.90)$,

$\eta_{e}$ - efficiency of the power electronic converter $\left(\eta_{e}=0.98\right)$.

The energy consumed by the vehicle in a given calculation step is expressed by the relationship:

$$
E_{p n}=\frac{\left(A \cdot I_{t n}+I_{w}\right) \cdot U_{n} \cdot \Delta t_{n}}{3600}
$$

where:

$E_{p n}$ - energy consumed by the vehicle in the $\mathrm{n}^{\text {th }}$ calculation step [kWh],

$I_{t n}$ - current of the traction needs in the $\mathrm{n}^{\text {th }}$ step of calculation $[\mathrm{A}]$,

$I_{w}-$ current of non-traction needs [A],

$A$ - logical condition of energy consumption for traction purposes $\left(\mathrm{I}_{t} \geq 0\right)$, thrue: $\mathrm{A}=1$, false: $\mathrm{A}=0$,

$\Delta_{t n}$ - time increment in the $\mathrm{n}^{\text {th }}$ calculation step [s].

The energy recovered as a result of recuperative braking in a given calculation step is given by the relationship:

$$
E_{o n}=\frac{B \cdot\left|I_{t n}\right| \cdot U_{n} \cdot \Delta t_{n}}{3600}
$$

where:

$E_{o n}$ - energy recovered by the vehicle in the $\mathrm{n}^{\text {th }}$ calculation step $[\mathrm{kWh}$,

$B$ - logical condition of energy recovery $(\mathrm{It}<0)$, thrue: $\mathrm{B}=1$, false: $\mathrm{B}=0$.

The energy balance of the vehicle is expressed as the difference of energy collected and recovered during the entire trip, calculated on the basis of the relationship:

$$
E_{B}=\sum_{i=0}^{n} E_{p i}-\sum_{i=0}^{n} E_{o i}
$$

where:

$E_{B}$ - energy balance (energy used irretrievably)

[kWh],

$E_{p i}$ - energy consumed by the vehicle in the i-th step of calculation [kWh],

$E_{o i}$ - energy recovered by the vehicle in the i-th step of calculation [kWh].

The results of the calculations of the energy balance are presented for one driving direction in Table 3 and Figure 11.

\subsection{The required technical characteristics of the storage electric multiple unit}

The performed calculations of the energy balance make it possible to determine the technical characteristics of the storage train set. A hybrid energy storage $\eta_{p}$ - sprawność przekładni mechanicznej $\left(\eta_{p}=\right.$ $0,98)[-]$,

$\eta_{s}$ - sprawność sinika trakcyjnego $\left(\eta_{s}=0,90\right)[-]$,

$\eta_{e}-$ sprawność przekształtnika energoelektronicznego $\left(\eta_{e}=0,98\right)[-]$.

Energia pobrana przez pojazd w danym kroku obliczeniowym wyrażana jest zależnością:

gdzie:

$$
E_{p n}=\frac{\left(A \cdot I_{t n}+I_{w}\right) \cdot U_{n} \cdot \Delta t_{n}}{3600}
$$

$E_{p n}$ - energia pobrana przez pojazd w n-tym kroku obliczeniowym [kWh],

$I_{t n}$ - prąd potrzeb trakcyjnych w n-tym kroku obliczeniowym $[\mathrm{A}]$,

$I_{w}$ - prąd potrzeb nietrakcyjnych [A],

$A$ - warunek logiczny poboru energii na cele trakcyjne ( $\mathrm{I}_{\mathrm{t}}$ ? 0), prawda: $\mathrm{A}=1$, fałsz: $\mathrm{A}=0$,

$\Delta_{t n}-$ przyrost czasu $\mathrm{W}$ n-tym kroku obliczeniowym [s].

Energię odzyskaną w wyniku hamowania rekuperacyjnego w danym kroku obliczeń określa zależność:

$$
E_{o n}=\frac{B \cdot\left|I_{t n}\right| \cdot U_{n} \cdot \Delta t_{n}}{3600}
$$

gdzie:

$E_{\text {on }}$ - energia odzyskana przez pojazd w n-tym kroku obliczeniowym [kWh],

$B$ - warunek logiczny odzysku energii $(\mathrm{It}<0)$, prawda: $\mathrm{B}=1$, fałsz: $\mathrm{B}=0$.

Bilans energetyczny pojazdu wyrażony jest jako różnica energii pobranej i odzyskanej w trakcie całego przejazdu obliczono na podstawie zależności:

$$
E_{B}=\sum_{i=0}^{n} E_{p i}-\sum_{i=0}^{n} E_{o i}
$$

gdzie:

$E_{B}-$ bilans energii (energia zużyta bezpowrotnie) [kWh],

$E_{p i}$ - energia pobrana przez pojazd w i-tym kroku obliczeniowym [kWh],

$E_{o i}$ - energia odzyskana przez pojazd w i-tym kroku obliczeniowym [kWh].

Wyniki przeprowadzonych obliczeń bilansu energetycznego przedstawiono dla jednego kierunku jazdy w tablicy 3 oraz na rysunku 11 .

\subsection{Wymagana charakterystyka techniczna zasob- nikowego elektrycznego zespołu trakcyjnego}

Przeprowadzone obliczenia bilansu energetycznego pozwalają na określenie charakterystyki technicznej zasobnikowego zespołu trakcyjnego. Przyjęto hybrydowy zasobnik energii złożony $\mathrm{z}$ baterii akumulatorów, stanowiącej podstawowe źródło energii oraz 
List of the results of calculating the energy balance along the route Reda - Hel

Table 3

Zestawienie wyników obliczeń bilansu energetycznego na trasie Reda - Hel

Tablica 3

\begin{tabular}{|l|l|l|l|}
\hline Section & \multicolumn{1}{|c|}{$\begin{array}{c}\text { Energy taken } \\
{[\mathrm{kWh}]}\end{array}$} & \multicolumn{1}{|c|}{$\begin{array}{c}\text { Energy recovered } \\
{[\mathrm{kWh}]}\end{array}$} & $\begin{array}{c}\text { Energy balance } \\
{[\mathrm{kWh}]}\end{array}$ \\
\hline Reda - Reda Rekowo & 23.774 & 9.133 & 14.641 \\
\hline Reda Rekowo - Mrzezino & 39.282 & 8,033 & 31.249 \\
\hline Mrzezino - Żelistrzewo & 12,622 & 12,585 & 0.037 \\
\hline Żelistrzewo - Puck & 20,465 & 9.505 & 10.961 \\
\hline Puck - Swarzewo & 20.099 & 9.355 & 10.743 \\
\hline Swarzewo -Władysławowo & 31.807 & 8.074 & 23.734 \\
\hline Władysławowo - Władysławowo Port & 9.095 & 4.745 & 4.350 \\
\hline Władysławowo Port - Chałupy & 29.197 & 9.126 & 20,070 \\
\hline Chałupy - Kuźnica & 30.724 & 8.970 & 21.754 \\
\hline Kuźnica - Jastarnia Wczasy & 26.810 & 9.106 & 17.703 \\
\hline Jastarnia Wczasy - Jastarnia & 7.79 & 3.439 & 3.940 \\
\hline Jastarnia - Jurata & 1.773 & 9.291 & 10.482 \\
\hline Jurata - Hel & 43.847 & 9.142 & 34.705 \\
\hline Total & 314.873 & 110.504 & 204.370 \\
\hline + ENERGY CONSUMPTION AT STOPS & 322.999 & - & 212.496 \\
\hline
\end{tabular}

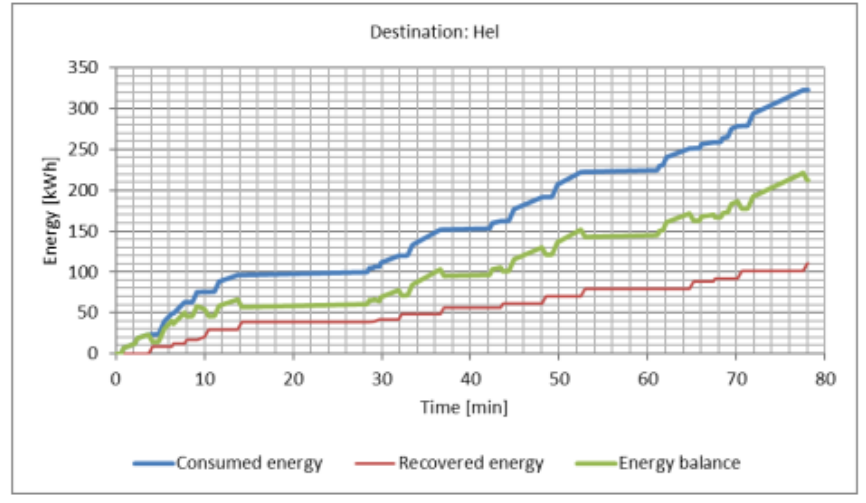

Fig. 11. Energy balance on the Reda - Hel route

Rys. 11. Bilans energetyczny na trasie Reda - Hel

was adopted, consisting of a battery of batteries, which is the basic source of energy, and supercapacitors, which are a storage that absorbs and returns energy in dynamic states. Table 4 presents technical data of the proposed, commercially available battery cells and supercapacitor units.

The next step in determining the technical characteristics of the on-board energy storage is to determine the number of parallel connected branches of battery cells and branches of supercapacitor units, due to the required capacity of both storage tanks and the limited maximum discharge current of a single branch of both storage tanks.

The calculation of the selection of the number of parallel branches of both reservoirs was based on the following assumptions:

- the maximum permissible level of discharge of both containers is $50 \%$

- during vehicle start-up, energy is mainly drawn from supercapacitors

- the energy recovered while driving is stored in supercapacitors and, to a lesser extent, in batteries superkondensatorów, będących zasobnikiem przejmującym i oddającym energię $w$ stanach dynamicznych. W tablicy 4 zamieszczono dane techniczne proponowanych, dostępnych na rynku ogniw akumulatorowych oraz jednostek superkondensatorowych.

Technical data of battery cells [21]

Table 4

Dane techniczne ogniw akumulatorowych [21]

Tablica 4

\begin{tabular}{|l|l|l|}
\hline Parametr & akumulator & superkondensator \\
\hline $\begin{array}{l}\text { Napięcie znamio- } \\
\text { nowe }\end{array}$ & $38,40 \mathrm{~V}$ & $62,10 \mathrm{~V}$ \\
\hline Pojemność & $50 \mathrm{Ah}$ & $130 \mathrm{~F}$ \\
\hline $\begin{array}{l}\text { Energia nominal- } \\
\text { na }\end{array}$ & $1,92 \mathrm{kWh}$ & $69,63 \mathrm{Wh}$ \\
\hline Prąd rozładowania & $100 \mathrm{~A}$ & $2157 \mathrm{~A}$ \\
\hline $\begin{array}{l}\text { Prąd rozładowania } \\
30 \text { sekundowy }\end{array}$ & $150 \mathrm{~A}$ & $2157 \mathrm{~A}$ \\
\hline Wymiary & $225 \times 172 \times 306 \mathrm{~mm}$ & $\begin{array}{l}634 \times 176 \times 173 \\
\mathrm{~mm}\end{array}$ \\
\hline Masa & $18,70 \mathrm{~kg}$ & $16 \mathrm{~kg}$ \\
\hline
\end{tabular}

Kolejnym etapem określenia charakterystyki technicznej pokładowego zasobnika energii jest wyznaczenie liczby równolegle połączonych gałęzi ogniw akumulatorowych oraz gałęzi jednostek superkondensatorowych, ze względu na wymaganą pojemność obu zasobników oraz ograniczony maksymalny prądu rozładowania pojedynczej gałęzi obu zasobników.

Obliczenia doboru liczby gałęzi równoległych obu zasobników oparto na następujących założeniach:

- maksymalny dopuszczalny poziom rozładowania obu zasobników wynosi 50\%

- podczas rozruchu pojazdu energia pobierana jest głownie z superkondensatorów

- odzyskiwana w trakcie jazdy energia gromadzona jest $\mathrm{w}$ superkondensatorach oraz $\mathrm{w}$ mniejszym stopniu w akumulatorów 
- energy from the battery is collected to cover the vehicle's own needs, while driving at a constant speed and to recharge supercapacitors when parked

- the energy storage is fully charged when entering a non-electrified section towards Hel station.

Based on these assumptions, the number of series elements of a single battery branch and a single branch of supercapacitors was calculated in order to obtain the required voltage level in the vehicle's onboard network. It is necessary to use 52 cells in a single branch of the battery bank, thanks to which the energy of $99.84 \mathrm{kWh}$ of a single branch is accumulated. In the case of a supercapacitor chain, 15 units should be connected in series, which results in the collected energy of a single branch of $2.31 \mathrm{kWh}$. In the case of a more energy-intensive journey (towards Hel - Reda), the energy balance was $213.4 \mathrm{kWh}$. In order to provide the required amount of energy, while assuming the permissible level of battery discharge at $50 \%$, the minimum energy of the battery bank is $426.8 \mathrm{kWh}$. Therefore, the number of battery branches was determined to be 5 .

The number of branches of the supercapacitor store is determined by the amount of energy consumed during the most energy-consuming start-up with the permissible discharge of the supercapacitor store to $50 \%$. The vehicle consumes the highest energy of $16.3 \mathrm{kWh}$ when starting from the Reda Rekowo station towards Hel station. The required number of branches of the supercapacitor storage was determined as 16 .

At the Hel station, the batteries are charged to their full capacity with the maximum charging current, assuming the use of one pantograph, for which, in accordance with PN-EN 50367: 2012, the permissible current value during standstill is $200 \mathrm{~A}$. The value of the current collected from the traction network, taking into account the current consumption of the battery charging and the vehicle's own needs, was calculated to be $175 \mathrm{~A}$.

Charging the accumulator with the maximum current is possible because the value of the total current consumed from the mains during the charging of the container does not exceed the maximum pantograph current. The maximum charging current of the supercapacitor reservoir on the $3 \mathrm{kV}$ side is $2057 \mathrm{~A}$, therefore it is necessary to limit this current so that the total current drawn from the overhead contact line when charging the supercapacitor reservoir does not exceed the permissible pantograph current. Alternatively, consideration could be given to equip the trainset with two pantographs. Figure 12 shows the courses of the charge level of batteries and supercapacitors during driving on a non-electrified section. It has been assumed that the battery is charged during a stop at the Hel terminal station and while driving on the electrified section Reda - Gdynia Gł. and possibly during a
- energia $\mathrm{z}$ baterii akumulatorów pobierana jest $\mathrm{w}$ celu pokrycia potrzeb własnych pojazdu, podczas jazdy ze stała prędkością oraz w celu doładowania superkondensatorów na postoju

- zasobnik energii zostaje w pełni naładowany przy wjeździe na odcinek niezelektryfikowany w kierunku Helu.

Na podstawie tych założeń obliczono liczbę elementów szeregowych pojedynczej gałęzi akumulatorów oraz pojedynczej gałęzi superkondensatorów w celu uzyskania wymaganego poziomu napięcia $\mathrm{w}$ sieci pokładowej pojazdu. W pojedynczej gałęzi baterii akumulatorów konieczne jest zastosowanie 52 ogniw, dzięki czemu osiagana jest gromadzona energia 99,84 $\mathrm{kWh}$ pojedynczej gałęzi. W przypadku łańcucha superkondensatorów w szeregu należy połączyć 15 jednostek, co daje w efekcie zgromadzona energia pojedynczej gałęzi 2,31 kWh. W przypadku bardziej energochłonnego przejazdu (w kierunku Hel - Redy) bilans energii wyniósł $213,4 \mathrm{kWh}$. W celu zapewnienia wymaganej ilości energii przy jednoczesnym założeniu dopuszczalnego poziomu rozładowania baterii akumulatorów na poziomie $50 \%$, minimalna energia baterii akumulatorów wynosi 426,8 kWh. Wyznaczono zatem liczbę gałęzi baterii akumulatorów równą 5 . Liczba gałęzi zasobnika superkondensatorowego determinowana jest ilością energii pobranej przy najbardziej energochłonnym rozruchu przy dopuszczalnym rozładowaniu zasobnika superkondensatorowego do $50 \%$. Pojazd pobiera największą energię $16,3 \mathrm{kWh}$ przy rozruchu ze stacji Reda Rekowo w kierunku Helu. Wymaganą liczbę gałęzi zasobnika superkondensatorowego określono na 16.

$\mathrm{Na}$ stacji Hel następuje naładowanie do pełnej pojemności baterii akumulatorów maksymalnym prądem ładowania przy założeniu wykorzystania jednego pantografu, dla którego zgodnie z normą PN-EN 50367:2012 dopuszczalna wartość prądu podczas postoju wynosi $200 \mathrm{~A}$. Wartość prądu pobieranego $\mathrm{z}$ sieci trakcyjnej przy uwzględnieniu poboru prądu ładowania baterii akumulatorów oraz prądu potrzeb własnych pojazdu obliczono wyniósł $175 \mathrm{~A}$

Ładowanie baterii akumulatorów maksymalnym prądem jest możliwe, ponieważ wartość całkowitego prądu pobieranego $\mathrm{z}$ sieci podczas ładowania zasobnika nie przekracza maksymalnego prądu pantografu. Maksymalny prąd ładowania zasobnika superkondensatorowego po stronie $3 \mathrm{kV}$ wynosi $2057 \mathrm{~A}$, zatem konieczne jest ograniczenie tego prądu tak, aby łączny prąd pobierany $\mathrm{z}$ sieci trakcyjnej podczas ładowania zasobnika superkondensatorowego nie przekraczał dopuszczalnego prądu pantografu. Ewentualnie można rozważyć wyposażenie zespołu trakcyjnego w dwa pantografy.

$\mathrm{Na}$ rysunku 12 przedstawiono przebiegi poziomu naładowania baterii akumulatorów oraz superkondensatorów podczas jazdy na odcinku niezelektryfikowanym. Przyjęto założenie, że bateria akumulatorów jest 
stop at the Gdynia G1. station. The maximum depth of battery discharge was $59 \%$, and the time of full charging was 25 minutes. In the case of two pantographs, the charging time would be 14 minutes. For the supercapacitor, it was assumed that it was recharged from batteries at specific stations. The decision to carry out a charging at a given stop and to what value the supercapacitor will be recharged were made on the basis of the analysis of the supercapacitor charge level without recharging at the stops. The supercapacitor is recharged at the stops where starting would discharge it below $50 \%$ of capacity. The level of boost at individual stops has been determined taking into account the predicted subsequent regenerative braking. This situation may occur on sections where starting and braking take place with a negative route profile, resulting in low energy consumption at start-up and high energy recovery during braking. The minimum charge level of the supercapacitor on the analyzed route is $53 \%$. At the Hel end station, the supercapacitor is recharged to $100 \%$ capacity within 35 seconds after the battery is charged.

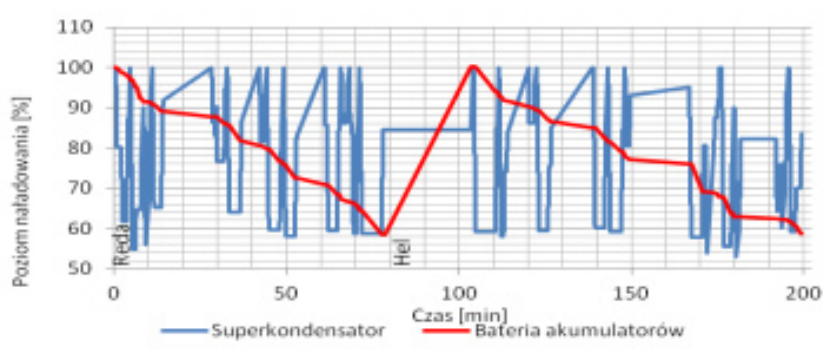

Fig. 12. The courses of loading the storages during the passage on line 213 in both directions

Rys. 12. Przebiegi naładowania zasobników podczas przejazdu na linii 213 w obu kierunkach

Table 5 shows the data of the on-board energy storage used. The total weight and cost of the hopper has been increased by $30 \%$ to accommodate the hopper hardware, including power electronic converters, fans and auxiliary systems.

\subsection{Requirements for charging stations at the Hel station}

In the peak of the tourist season, regional trains reach $\mathrm{Hel}$ at minimum time intervals of 14 minutes. The total loading time of the accumulator of a traction unit with one pantograph is $25 \mathrm{~min} 35 \mathrm{~s}$, which means that the accumulator loading station should enable simultaneous loading of two traction vehicles. Table 6 shows the values of the current collected from the 3 $\mathrm{kV}$ overhead contact line and the charging time of the multiple unit with one and two pantographs. Assuming that two vehicles are charged simultaneously, the minimum required power of a traction substation is 2.1 MW. ładowana podczas postoju na stacji końcowej Hel oraz podczas jazdy odcinkiem zelektryfikowanym Reda - Gdynia Gł. i ewentualnie podczas postoju na stacji Gdynia Gł. Maksymalna głębokość rozładowania akumulatora wyniosła $59 \%$, a czas pełnego ładowania 25 minut. $\mathrm{W}$ przypadku dwóch pantografów czas ładowania wyniósłby 14 minut. Dla superkondensatora przyjęto założenie jego doładowywania $\mathrm{z}$ baterii akumulatorów na określonych stacjach. Decyzje o przeprowadzeniu na danym przystanku ładowania oraz do jakiej wartości superkondensator zostanie doładowany podjęto na podstawie analizy przebiegu poziomu naładowania superkondensatora bez doładowywania na przystankach. Superkondensator doładowywany jest na przystankach, z których rozruch spowodowałby jego rozładowanie poniżej poziomu $50 \%$ pojemności. Stopień doładowania na poszczególnych przystankach został określony z uwzględnieniem prognozowanego kolejnego hamowania odzyskowego. Do sytuacji takiej dojść może na odcinkach, na których rozruch i hamowanie następują przy ujemnym profilu trasy, skutkującym niskim poborem energii przy rozruchu i dużym odzyskiem energii podczas hamowania. Minimalny poziom naładowania superkondensatora na analizowanej trasie wynosi $53 \%$. Na stacji końcowej Hel superkondensator zostaje doładowany do $100 \%$ pojemność w czasie 35 s po naładowaniu baterii akumulatorów.

Technical data of het on-board energy storage Table 5 Dane techniczne pokladowego zasobnika energii Tablica 5

\begin{tabular}{|c|c|c|}
\hline Parametr & $\begin{array}{l}\text { Bateria akumulato- } \\
\text { rów }\end{array}$ & Superkondensatory \\
\hline Napięcie gałęzi & $1996,4 \mathrm{~V}$ & $1987,2 \mathrm{~V}$ \\
\hline Pojemność & $499,2 \mathrm{kWh}$ & $35,6 \mathrm{kWh}$ \\
\hline $\begin{array}{l}\text { Maksymalny } \\
\text { ciagły prąd i } \\
\text { moc rozłado- } \\
\text { wania } \\
\end{array}$ & $500 \mathrm{~A}, 998,2 \mathrm{~kW}$ & $34,5 \mathrm{kA}, 68,6 \mathrm{MW}$ \\
\hline $\begin{array}{l}\text { Maksymalny } \\
\text { ciagły prąd i } \\
\text { moc ładowania }\end{array}$ & $250 \mathrm{~A}, 499,1 \mathrm{~kW}$ & $\begin{array}{l}34,5 \mathrm{kA}, \quad 68,6 \\
\mathrm{MW}\end{array}$ \\
\hline $\begin{array}{l}\text { Liczba jedno- } \\
\text { stek w gałę- } \\
\text { zi/liczba gałęzi }\end{array}$ & $52 / 5$ & $32 / 16$ \\
\hline $\begin{array}{l}\text { Ilość jednostek } \\
\text { łącznie }\end{array}$ & 260 & 512 \\
\hline Masa & $4,9 \mathrm{t}$ & $8,2 \mathrm{t}$ \\
\hline Koszt & 2146716 PLN & 3694745 PLN \\
\hline \multicolumn{3}{|c|}{ Hybrydowy zasobnik łącznie } \\
\hline $\begin{array}{l}\text { Pojemność } \\
\text { (energia zna- } \\
\text { mionowa) }\end{array}$ & $534,9 \mathrm{kWh}$ & \\
\hline Masa całkowita & $17 \mathrm{t}$ & \\
\hline Koszt całkowity & 7593900 PLN & \\
\hline
\end{tabular}


Charging variants at the Hel station Warianty ladowania na stacji Hel

\begin{tabular}{|l|l|l|l|}
\hline Parameter & $\begin{array}{c}\text { The current } \\
\text { is drawn } \\
\text { from the } \\
\text { catenary }\end{array}$ & $\begin{array}{c}\text { Charging } \\
\text { time }\end{array}$ & $\begin{array}{c}\text { Charging } \\
\text { power for } \\
\text { two multi- } \\
\text { ple units }\end{array}$ \\
\hline $\begin{array}{l}\text { Multiple units with } \\
\text { one pantograph }\end{array}$ & $175 \mathrm{~A}$ & $25.5 \mathrm{~min}$ & $1.05 \mathrm{MW}$ \\
\hline $\begin{array}{l}\text { Multiple units with } \\
\text { two pantographs }\end{array}$ & $350 \mathrm{~A}$ & $15 \mathrm{~min}$ & $2.10 \mathrm{MW}$ \\
\hline
\end{tabular}

\section{Summary}

In order to determine the technical and partly economic conditions for servicing the partly electrified Gdynia Główna - Hel route through storage multiple units, calculations were made of the theoretical passage and energy demand on the non-electrified section of the analyzed route. An on-board energy storage was selected, consisting of batteries with a total stored energy of approx. $500 \mathrm{kWh}$ and supercapacitors with a total stored energy of approx. $36 \mathrm{kWh}$. It has been shown that to charge vehicles at the Hel station, it is necessary to build a $2.1 \mathrm{MW}$ rectifier in a charging station.

It was proposed to operate the route using the Stadler Flirt electric multiple unit equipped with an on-board hybrid energy storage. The cost of such a vehicle is less than PLN 31 million. The cost of equipping it with an on-board energy storage is PLN 7.6 million, which means the total cost of PLN 38.6 million. A significant part of the cost of the on-board energy storage is the cost of supercapacitors, the price of which is PLN 3.7 million. The reduction of the purchase cost of a multiple unit is possible by resigning from equipping the vehicle with a supercapacitor. The technology of production of traction batteries is constantly being improved, which makes it possible to power storage trains without limiting the dynamics of the vehicle resulting from the limitation of charging and discharging currents of the battery. An example of a currently produced storage unit equipped only with a battery of accumulators is Bombardier Talent 3 , which enables driving $40 \mathrm{~km}$ with battery power, and its cost amounts to PLN 27 million. It has therefore been shown that on the Hel Peninsula, which is very attractive for tourists, it is possible to replace combustion units in passenger transport with modern electric vehicles with underlying energy storage.

In the next article, the authors will present the developed multi-variant decision model and its use to perform a comparative analysis of the operation of the discussed line by the current combustion units, classic electric units and modern storage electric multiple units.
W tablicy 5. przedstawiono dane zastosowanego pokładowego zasobnika energii. Całkowita masę oraz koszt zasobnika zwiększono o $30 \% \mathrm{w}$ celu uwzględnienia osprzętu zasobnika, w którego skład wchodza m.in. przekształtniki energoelektroniczne, wentylatory oraz układy pomocnicze.

\subsection{Wymagania dla stacji ladowania na stacji Hel}

W szczycie sezonu turystycznego pociagi regionalne do Helu docierają w minimalnych odstępach czasowych 14 minut. Całkowity czas ładowania zasobnika pojazdu trakcyjnego z jednym pantografem wynosi 25 min $35 \mathrm{~s}$, co oznacza, że stacja ładowania zasobników powinna umożliwiać jednoczesne ładowanie dwóch pojazdów trakcyjnych. W tablicy 6 zamieszczono wartości prądu pobieranego $\mathrm{z}$ sieci trakcyjnej $3 \mathrm{kV}$ oraz czas ładowania zespołu trakcyjnego $\mathrm{z}$ jednym $\mathrm{i}$ dwoma pantografami. Przy założeniu ładowania dwóch pojazdów jednocześnie, minimalna wymagana moc podstacji trakcyjnej wynosi 2,1 MW.

\section{PODSUMOWANIE}

W celu określenia technicznych i częściowo ekonomicznych warunków obsługi częściowo zelektryfikowanej trasy Gdynia Główna - Hel przez zasobnikowe zespoły trakcyjne wykonano obliczenia przejazdu teoretycznego oraz zapotrzebowania energetycznego na niezelektryfikowanym odcinku analizowanej trasy. Dobrano pokładowy zasobnik energii składający się z baterii akumulatorów o łącznej gromadzonej energii ok. $500 \mathrm{kWh}$ oraz superkondensatorów o łącznej gromadzonej energii ok. $36 \mathrm{kWh}$. Wykazano, że do ładowania pojazdów na stacji Hel niezbędne jest wybudowanie w stacji prostownikowej o mocy 2,1 MW. Zaproponowano obsługe trasy przy wykorzystaniu elektrycznego zespołu trakcyjnego Stadler Flirt doposażonego w pokładowy hybrydowy zasobnik energii. Koszt takiego pojazdu wynosi niespełna $31 \mathrm{mln}$ zł. Koszt wyposażenia go w pokładowy zasobnik energii to 7,6 mln zł, co oznacza łączny koszt Łączny 38,6 mln zł. Znaczną część kosztu pokładowego zasobnika energii stanowi koszt superkondensatorów, których cena wynosi 3,7 mln zł. Obniżenie kosztu zakupu zespołu trakcyjnego możliwa jest poprzez rezygnację $\mathrm{z}$ wyposażenia pojazdu w superkondensator. Technologia produkcji akumulatorów trakcyjnych nieustanie jest doskonalona, co daje możliwość zasilania zasobnikowych zespołów trakcyjnych bez ograniczania dynamiki pojazdu wynikającej z ograniczeń prądów ładowania oraz rozładowania baterii akumulatorów. Przykładem obecnie produkowanego zasobnikowego zespołu trakcyjnego wyposażonego wyłącznie w baterię akumulatorów jest Bombardier Talent 3, który umożliwia przejechanie $40 \mathrm{~km}$ przy zasilaniu bateryjnym, a jego koszt wynosi $27 \mathrm{mln}$ zł.

Wykazano zatem, że na bardzo atrakcyjnym turystycznie Półwyspie Helskim można w przewozach 


\section{BIBLIOGRAPHY / BIBLIOGRAFIA}

[1] Shiraki N., Tokito K., Yokozutsumi R.: Propulsion system for catenary and storage battery hybrid electric railcar series EV-E301 2015 International Conference on Electrical Systems for Aircraft, Railway, Ship Propulsion and Road Vehicles (ESARS), Tokio, Japonia $2015 r$.

[2] Japanese Railway Information No.136, Series BEC819 „DENCHA” Battery-powered Train Charged from AC Overhead Lines, Tokio, Japonia $2016 r$.

[3] trafficnews.jp, JR Kyushu will replace the Kashii Line trains with BEC819 trains "DENCHA", https://trafficnews.jp/post/82377 (data dostępu 19.02.2020 r.)

[4] response.jp, JR East to introduce storage battery train "EV-E801 series" on Oga Line, https://response.jp/article/2015/11/20/264656.html, (data dostęu 19.02.2020 r.)

[5] railway-technology.com, Independently Powered Electric Multiple-Unit (IPEMU), Essex, https://www.railway-

technology.com/projects/independently-poweredelectric-multiple-unit-ipemu-essex/, (data dostęu 20.02.2020 r.)

[6] www.stadlerrail.com, WINK BMU / WINK ZERO EMISSION Arriva Netherlands, Noordelijke Lijnen franchise - Preliminary datasheet, (data dostepu 20.02.2020

https://www.stadlerrail.com/media/pdf/warr0517e print.pdf, (data dostęu 20.02.2020 r.)

[7] pgt.pl, WINK - nowy typ pojazdu, Pierwszym klientem holenderska Arriva, https://www.rynekkolejowy.pl/wiadomosci/stadler-wprowadza-nowytyp-pojazdu-wink-pierwszym-klientem-holenderskaarriva--84613.html, (data dostepu 20.02.2020 r.)

[8] rynek-kolejowy.pl, Debiut Flirta Akku. Do 80 kilometrów bez sieci trakcyjnej, https://www.rynekkolejowy.pl/mobile/tylko-u-nas-debiut-flirta-akkudo-80-kilometrow-bez-sieci-trakcyjnej-88700.html, (data dostęu 21.02.2020 r.)

[9] rynek-kolejowy.pl, Stadler zdobędzie zamówienie na 55 Flirtów Akku dla Szlezwiku-Holsztynu, https://www.rynek-kolejowy.pl/wiadomosci/stadlerzdobedzie-zamowienie-na-55-flirtow-akku-dlaszlezwikuholsztynu-92446.html, (data dostępu 21.02.2020 r.)

[10] railway-technology.com, Desiro ML Cityjet eco Passenger Train, https://www.railwaytechnology.com/projects/desiro-ml-cityjet-ecopassenger-train/, (data dostęu 22.02.2020 r.)

[11] assets.new.siemens.com, Desiro ML ÖBB Cityjet eco for ÖBB Personenverkehr $A G$, https://assets.new.siemens.com/siemens/assets/api/u uid:b26911b1-2b0e-48b4-b593-81adbf032d75/dbdesiro-ml-oebb-cityjet-eco-e.pdf, (data dostępu 22.02.2020 r.)

[12] railway-news.com, OEBB Cityjet Eco to Be Deployed in Greater Vienna, https://railwaynews.com/oebb-cityjet-eco-to-be-deployed-ingreater-vienna/ (data dostęu 22.02.2020 r.) pasażerskich zastąpić zespoły spalinowe nowoczesnymi elektrycznymi pojazdami z podkładowymi zasobnikami energii.

Autorzy w kolejnym artykule przedstawią opracowany wielowariantowy model decyzyjny i jego wykorzystanie do wykonania analizy porównawczej obsługi omawianej linii przez obecne zespoły spalinowe, klasyczne zespoły elektryczne oraz nowoczesne zasobnikowe elektryczne zespoły trakcyjne.

[13] forsal.pl, Pociag na akumulator. Bombardier zadebiutowat ze sktadem Talent 3, https://forsal.pl/artykuly/1257389,bombardiertalent-3-pociag-na-akumulator-bombardierzadebiutowal-ze-skladem-talent-3.html,

(data dostępu 23.02.2020 r.)

[14] railjournal.com, Bombardier unveils battery electric Talent 3, https://www.railjournal.com/fleet/bombardierunveils-battery-electric-talent-3/, (data dostęu 23.02.2020 r.)

[15] railway-technology.com, Bombardier to deliver 300 Talent 3 trains in Austria for \$1.9bn, https://www.railway-

technology.com/news/newsbombardier-to-deliver300-talent-3-trains-in-austria-for-19bn-5707929/, (data dostępu 23.02.2020 r.)

[16] industriemagazin.at, Bombardier liefert den ÖBB den ersten Cityjet "Talent 3" nach Vorarlberg, https://industriemagazin.at/a/bombardier-liefertden-oebb-den-ersten-cityjet-talent-3-nachvorarlberg, (data dostęu 23.02.2020 r.)

[17] alstom.com, Alstom signs first contract for batteryelectric regional trains in Germany, https://www.alstom.com/press-releasesnews/2020/2/alstom-signs-first-contract-batteryelectric-regional-trains-germany, (data dostęu 24.02.2020 r.)

[18] traction-electrique.ch, Elektrischer Niederflurtriebzug FLIRT für die Abellio GmbH http://www.traction-

electrique.ch/documents/FLIRT23.pdf, (data dostęu 29.04.2020 r.)

[19] Barttomiejczyk M, Jarzębowicz L., Judek S., Karkosińska-Brzozowska N., Karwowski K., Mizan M., Skibicki J., Wilk A.: Energetyka transportu zelektryfikowanego: Poradnik inżyniera, pod redakcja Krzysztofa Karwowskiego, Gdańsk 2018 r.

[20] geoserwis.gdos.gov.pl, Mapa obszarów Natura 2000, http://geoserwis.gdos.gov.pl/mapy/ (data dostępu 20.08.2020 r.)

[21] lithiumwerks.com, Karta katalogowa Lithium Werks U27-36P, https://lithiumwerks.com/ data-sheetdownloads/ (data dostęu 29.04.2020 r.) 